\title{
Combination of Curcuma (Curcuma xanthorriza Roxb) Rhizome Ethanolic Extract and Awar-Awar (Ficus septica Burm.F) Leaves Ethanolic Extract Increases Cisplatin Cytotoxicity on T47D Breast Cancer Cells through Cell Cycle Modulation
}

\author{
Devi Nisa Hidayati ${ }^{2}$, Riris Istighfari Jenie ${ }^{1}$, Edy Meiyanto $^{1^{*}}$ \\ ${ }^{1}$ Department of Pharmaceutical Chemistry, Faculty of Pharmacy, Universitas Gadjah Mada, Indonesia \\ ${ }^{2}$ Faculty of Pharmacy, Universitas Wahid Hasyim, Indonesia
}

\begin{abstract}
Curcuma (Curcuma xanthorriza Roxb.) and Awar-awar ((Ficus septica Burm.f.) are well known to have anticancer potential especially for breast cancer with low toxicity. This study aims to examine the potential effect of the combination of Curcuma ethanolic extracts (CEE) and awarawar leaves ethanolic extract (AEE) to increase the efficacy of cisplatin toward T47D breast cancer cells. The combination activity was done using 3 series of concentration, I/3; I/6 and I/I 2 of $I C_{50}$, to determine the combination index $(\mathrm{Cl})$ of cisplatin, CEE and AEE under MTT assay. The result showed that the combination of $2.5 \mu \mathrm{M}, 5 \mu \mathrm{g} / \mathrm{mL}, \mathrm{I} \mu \mathrm{g} / \mathrm{mL}$ concentrations of cisplatin, CEE and AEE respectively result in synergistic effect with $\mathrm{Cl}$ values less than I. The treatment exhibited the cell accumulation in S phase (27.7\%) against T47D breast cancer cells confirmed through cell cycle examination by flow cytometry. These results provided the evidence that the CEE and the AEE can be developed as co-chemotherapeutic agents combined with cisplatin to improve the effectiveness of breast cancer treatment.
\end{abstract}

Keywords : Curcuma xanthorriza Roxb., Ficus septica Burm.f., cisplatin, cell cycle

\section{INTRODUCTION}

Breast cancer generally affects women (Siegel, et al., 2014), with an estimated $23 \%$ of the total cancer cases and $14 \%$ death (Jemal, et al., 2011). Breast cancers occur in Asian women per 100,000 , and Indonesia is the first position with 25,208 cases (IARC, 2013). To date, cisplatin is still being first line chemotherapeutic agent (Dhar, et al., 2011). However, cisplatin remains causing side effects, such as neurotoxicity, nephrotoxicity and bone marrow suppression (Milosavlievic, et al., 2010). The other case found that in the continuous use of cisplatin causes resistance through changes in the cellular uptake, efflux of drug, inhibition of apoptosis and increased DNA repair (Florea and Busselberg, 2011). In this case, we should consider to maintain the dose of cisplatin.

Combination chemotherapy is common application to cure cancer for more effective eradication (Zhao, et al., 2004). Currently, the use of herbal medicine as the complementary cancer therapy is prefer chosen one due to its safe and affordable. The use of herbal medicinal as combinatorial chemotherapy is expected to reduce the dose of chemotherapeutic agents.

Curcuma (Curcuma xanthorriza Roxb) as the herbal medicine of Indonesia is known to contain curcumin that have anticancer activity through inhibition of cell proliferation and angiogenesis as well as inhibition of NF- $\mathrm{KB}$ activation (Foo and Nolan, 1999). Meanwhile, fenantroindolisidin alkaloid that present in awar-awar (Ficus septica Burm. F.) exhibits cytotoxic activity on HCT-8, NUGC, and Hone-1 cells (Damu, et al., 2009). Sekti, et.al. (2010) reported that ethanolic extract of awarawar performed cytotoxic activity suspected to induce apoptosis through apoptosis induction against MCF-7 cells.

\footnotetext{
*Corresponding author e-mail: edy_meiyanto@ugm.ac.id
} 
Based on these studies, curcuma extract and awarawar leaves extract are potential for cochemoteraphy in the treatment of breast cancer. This study was conducted to examine the synergistic effect the combination of curcuma ethanolic extract (CEE) and awar-awar leaves ethanolic extract (AEE) with cisplatin through induction of apoptosis and cell cycle modulation on T47D breast cancer cells.

\section{MATERIAL AND METHOD}

\section{Extract preparation and cell culture}

Curcuma and Awar-awar leaves were collected from Balai Besar Pusat Penelitian Tanaman Obat dan Obat Tradisional (B2P2TOOT), Tawangmangu, Indonesia. The dried powder of the samples were macerated using ethanol 70\%. T47D breast cancer cells were obtained from Prof. Kawaichi (NAIST, Japan) were grown in high glucose DMEM culture medium containing Fetal Bovine Serum (FBS) $10 \% \quad(\mathrm{v} / \mathrm{v}), \quad 150 \mathrm{U} / \mathrm{mL}$ penicillin-150 $\mu \mathrm{g} / \mathrm{mL}$ streptomycin $(\mathrm{v} / \mathrm{v})$ and Fungizone $1.25 \mu \mathrm{g} / \mathrm{mL}$ (Gibco), $0.25 \%$ trypsinEDTA.

\section{MTT assay}

T47D cells were grown in 96 well plate $\left(8 \times 10^{3} /\right.$ well $)$ and incubated for 24 hours in $5 \% \mathrm{CO}_{2}$ incubator. Before treatment, the media was discarded then washed using 1x PBS (100 $\mu 1 /$ well). Cells were treated with AEE, CEE and cisplatin for 24 hours in $5 \% \mathrm{CO}_{2}$ incubator. MTT reagent $(0.5 \mathrm{mg} / \mathrm{mL})$ was added as much $100 \mu \mathrm{L} /$ well then incubated for 3 hours at $37^{\circ} \mathrm{C}$. Stopper solution (SDS $10 \%$ in $0.01 \mathrm{~N}$ $\mathrm{HCl}$ ) was added to stopped reaction and incubated overnight at room temperature. The absorbance was measured by using ELISA reader at $\lambda 595 \mathrm{~nm}$.

\section{Flowcytometry}

Cells $\left(5 \times 10^{5}\right.$ cells/wells $)$ were grown in 6 well plate then incubated for 24 hours and treated with CEE, AEE, and cisplatin (WAKO), and combination of them. For cell cycle analysis, the trypsinized adherent cells were collected and detected by adding flow cytometry reagent $(\mathrm{PI}+\mathrm{RNase}+$ Triton-X) then incubated for 10 minutes. The apoptotic cells were detected by using FLOUS-Annexin V Apoptosis Detection Kit. The cell suspension was transferred into a flow cytometer tube and cell cycle profiles were read by using flow cytometry FACS-Calibur. Data were analyzed with Flowing software to see the distribution of cells in each phase of the cell cycle.

\section{Statistical Analysis}

Cell viability was analyzed statistically by using one way ANOVA and Tukey HSD test. Statistical significance was placed at $p<0.05$.

\section{RESULTS}

\section{Cytotoxic effects of the combination of the AEE, CEE and Cisplatin in T47D Cells}

The results from MTT assay showed that AEE and CEE performed cytotoxic activity against T47D with the $\mathrm{IC}_{50}$ values of $7 \pm 0.65 \mu \mathrm{g} / \mathrm{mL}$ and $29.3 \pm 1.76 \mu \mathrm{g} / \mathrm{mL}$ respectively. According to Ueda, et al., 2002, these results exhibit potential strong cytotoxic activity which are smaller than $100 \mu \mathrm{g} / \mathrm{mL}$. Whereas $\mathrm{IC}_{50}$ value of cisplatin is $14.7 \pm 0.52 \mu \mathrm{m}$. For further experiment to examine the combination effect, we used concentrations of each agent at $1 / 3$, $1 / 6$, and $1 / 12$ of $\mathrm{IC}_{50}$ values. The results showed changes in cell morphology and cell density. This cmbinatin treatment also decrease cell viability significantly compared with single treatment of cisplatin $(p<0.05)$.

$2.5 \mu \mathrm{M}$ cisplatin combination treatment, 1 $\mathrm{mg} / \mathrm{mL}$ AEE and $5 \mathrm{mg} / \mathrm{mL}$ T47D able to reduce cell viability by $52.69 \%$ (Fig. 1) compared with control cells that had been incubated for 24 hours and the $\mathrm{CI}$ (combination value) was 0.58 (Table 1). These results show the combination AEE and CEE can be used as cochemotherapy agents to lower the dose of cisplatin in the treatment of breast cancer. 


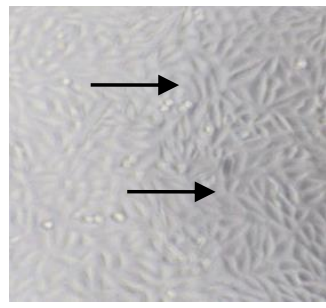

(a)

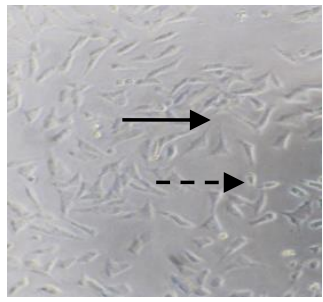

(c)

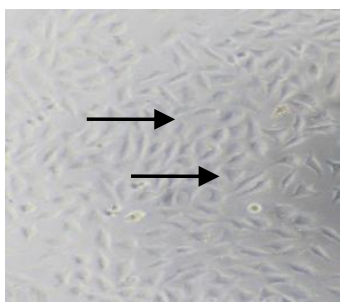

(b)

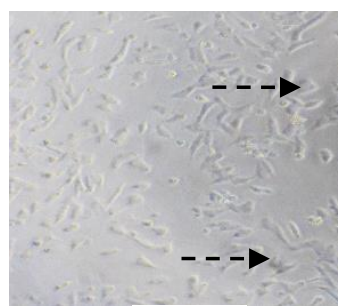

(d)

Figure I. The effect of combination treatment of AEE, CEE and Cisplatin on T47D cell growth. Cells of 8000 cells/wells in 96-well plates, incubated for 24 hours in DMEM Hi-glucose medium without or with CEE. The observations were performed under an inverted microscope with 100x magnification. (a) Cell control; (b) Combination of I/I2 IC 50 ; (c) Combination of I/6 IC 50 ; (d) Combination of I/3 IC 50 . The morphology of T47D cells that live with arrows $(\longrightarrow$ ) and cells undergoing morphological changes with broken arrows $(-\rightarrow)$ ). The combined $\mathrm{Cl}$ values of $\mathrm{AEE}, \mathrm{CEE}$ and cisplatin showed a synergistic effect $(\mathrm{Cl}<\mathrm{l})$.

Table I. Combination Index $(\mathrm{Cl})$ value cisplatin with CEE and AEE in T47D cells

\begin{tabular}{ccc}
\hline Ratio of Concenration & Cell viability (\%) & Cl \\
\hline I/I I IC 50 & 59,98 & 0,49 \\
I/6 IC 50 & 47,3 I & 0,53 \\
I/3 IC 50 & 40,26 & 0,76 \\
\hline
\end{tabular}

\section{Combination AEE, CEE and Cisplatin Modulate Cell Cycle in T47D Cells}

The results showed that the AEE causes accumulation in $\mathrm{S}$ phase, whereas the CEE accumulation in $\mathrm{S}$ phase and G2/M. Cisplatin accumulation in $\mathrm{S}$ phase, and combination AEE, $\mathrm{CEE}$ and cisplatin causes an accumulation of cells in $\mathrm{S}$ phase when compared with control cells. In the combination treatment of the percentage distribution of the cell cycle at S phase by $27.7 \%$ greater than the single cisplatin by $10.35 \%$. Accumulation of cells in S phase due to a combination of increased compared to cisplatin. Cell accumulation is possible due to cell cycle arrest in the phase .
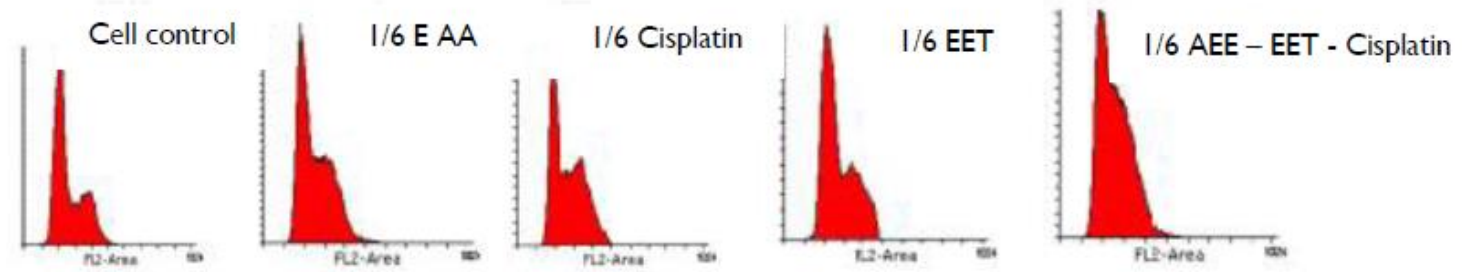

Figure 2. Detection of cell cycle distribution using flow cytometry. $5 \times 10^{5}$ cells were grown in 6 well plates and incubated 24 hours in high glucose DMEM medium without or with treatment. Flow cytometry detection using $\mathrm{PI}$ reagent against T47D cells after AEE treatment I $\mu \mathrm{g} / \mathrm{ml}$, CEE $5 \mu \mathrm{g} / \mathrm{ml}$. 


\section{Combination AEE, CEE and Cisplatin has not been able to Death Cell Apoptosis in Cells T47D}

Analysis of the percentage of cell death after treatment CEE, AEE, cisplatin and their combination shows untreated cells showed the percentage of cell life by $96.58 \%$ and amounted to $3.43 \%$ cell death. Cells that have a single treatment with the AEE shows cell death of $3.51 \%$; CEE showed treatment with cell death by $4.60 \%$; cisplatin treatment showed cell death at $6.59 \%$; while the third combination treatment (AEE, CEE and cisplatin) showed $11.85 \%$ cell death. It shows that the percentage of cell death AEE, CEE and cisplatin increased after the combination of the three. The third combination is able to increase cell death compared to single-agent cisplatin chemotherapy (2.5 m). Combination AEE, CEE and cisplatin can increase apoptosis by $5.26 \%$ compared with cisplatin single (Fig. 3).

\section{DISCUSSION}

Test compounds in the AEE and CEE by TLC shows alkaloid contained in the AEE and curcumin in CEE. In the CEE are curcumin at $11.586 \pm 0.4371 \%$ in the $10 \mathrm{mg}$ of extract, to can be concluded that ethanolic extract contain pf active compound. The results showed a combination of the
AEE (1 ug/mL), CEE (5 ug/mL) and cisplatin (2.5 $\mathrm{m})$ decrease cell viability by $39.32 \%$ against cisplatin $(2.5 \mathrm{~m})$. Combination exhibit $\mathrm{CI}$ values $<1$ that is equal to 0.58 , so the effect is synergistic.

Results of the study showed cell cycle modulating a single treatment with the AEE on T47D breast cancer cells led to accumulation in $\mathrm{S}$ phase $(27.7 \%)$ compared to $10.35 \%$ of control cells. In the CEE shows the result that the accumulation of cells occurs in $\mathrm{G} 2 / \mathrm{M}$ phase amounting to $23.28 \%$. CEE has been shown to contain compounds curcumin. curcumin is able to induce changes in cell cycle in cancer HT29 and Widr at G2/M phase (Kim, et al., 2005). Cisplatin showed modulating cell cycle at S phase by $24.66 \%$. This study is in line with previous research which reported that cisplatininduced S phase arrest in cell XP30RO where is associated with activity in reducing the expression of cyclin E and cyclin B (Cruet-Hennequart, et al., 2009). The treatment combination increases the number of cells that accumulate in S phase $(27.7 \%)$ were previously raised by cisplatin $(12.45 \%)$.

The combination of the presentation showed apoptosis of $10.54 \%$. AEE single treatment induced apoptosis by $3.01 \%$, CEE induces apoptosis of $3.77 \%$ and cisplatin showed apoptosis of $5.74 \%$. Combination showed apoptosis by $4.8 \%$ compared to cisplatin alone, combination can increased induction of apoptosis.

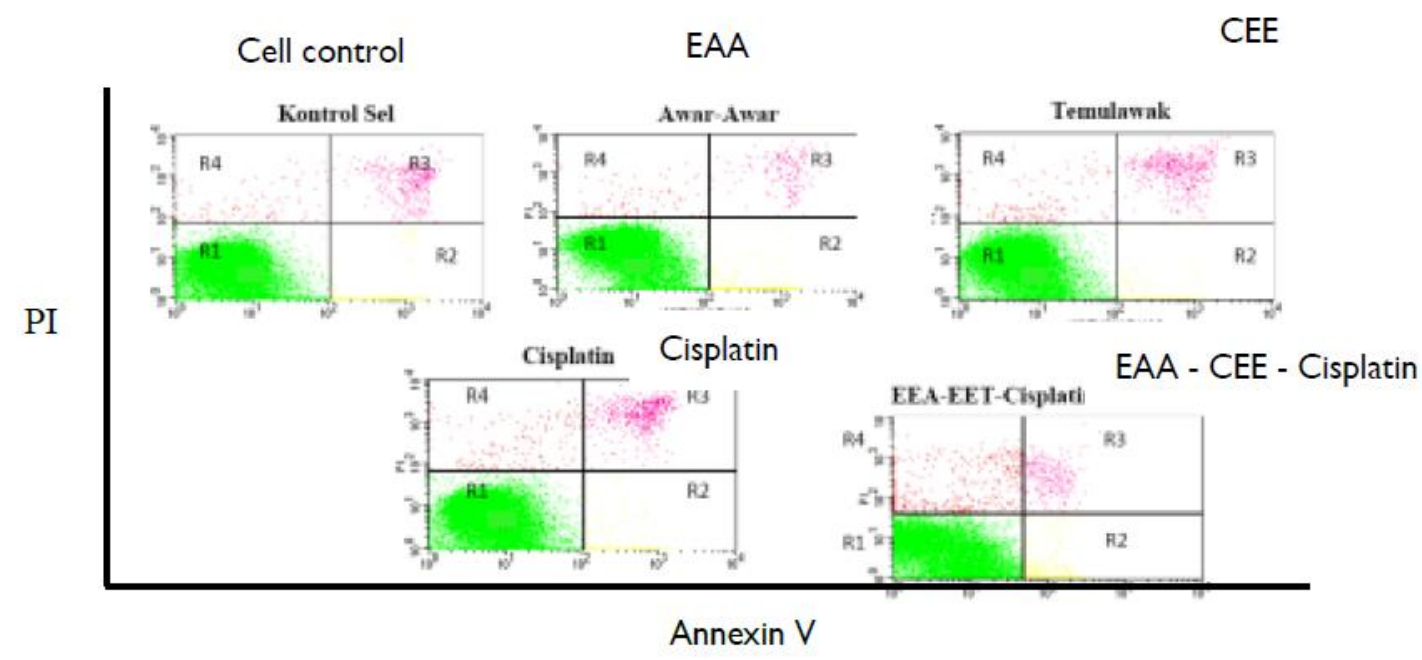

Figure 3. Effects of apoptotic induction after AEE, CEE, Cisplatin and combination of all three. Cells were grown with density $5 \times 10^{5}$ density in 6-well plates and incubated 24-hour selem in DMEM Hi-glucose medium without or with treatment. Detection of flow cytometry against cell death using Annexin V FLUOS on breast cancer cells T47D after treatment of I $\mu \mathrm{g} / \mathrm{mL} \mathrm{AEE,} 5 \mu \mathrm{g} / \mathrm{mL}$ CEE, $2.5 \mu \mathrm{M}$ Cisplatin and a combination of all three. Quadrant RI shows living cells, R2: early apoptosis, R3: late apoptosis, R4: necrosis. 


\section{CONCLUSION}

The conclusion of this research has been done that extract awar-awar and ginger extract has the potential to improve the T47D cancer cell sensitivity to cisplatin in vitro. Combination AEE, CEE and cisplatin have synergistic effects in giving cytotoxic effects on breast cancer cells by mechanisms of apoptosis induction and cell cycle pathways. Futher molecular target detection to investigate its cellular pathway needs to be conducted.

\section{REFERENCES}

Cruet-Hennequart, S., Villalan, S., Kaczmarczyk, A., O'Meara, E., Sokol, A.M. and Carty, M.P., 2009. Characterization of The Effect of Cisplatin and Carboplatin on Cell Cycle Progression and DNA Damage Response Activation in DNA Polymerase Eta-deficient Human Cells, Cell Cycle, 8(I8), 3039-3050.

Dalimartha, S., 2008, Kandungan Nutrisi \& Bioaktif Tahitain Noni Juice Membantu Mengatasi Kanker Payudara, Jakarta: Women Health Cancer.

Damu, A.G., Kuo, P.C., Shi, L.S., Li, C.Y., Su, C.R. and $\mathrm{Wu}, \quad$ T.S., 2009. Cytotoxic Phenanthroindolizine Alkaloids from the Roots of Ficus septica, Planta Med., 75(10), II52-II56.

Dhar, S.N., Kolishetti, S., Lippard and Farokhzad, 20II, Re: Targeted Delivery of a Cisplatin Prodrug for Safer and More Effective Prostate Cancer Therapy In Vivo, Proc. Natl. Acad. Sci. USA., I08(5) I850-1855.

Florea, M.A. and Busselberg, D., 20II, Cisplatin as an Anti-Tumor Drug : Celullar Mechanism of Activity, Drug Resistance and Induced Side Effects, Cancer, 3(4), |35 I-137|.

Foo, S.Y. and Nolan, G.P., 1999, NF-kappaB to the Rescue: RELs, Apoptosis and Cellular Transformation, Trends Genet., I5(6), 229235.
IARC, 2013, Latest World Cancer Statistics Global Cancer Burden Rises To I4.I Million New Cases In 2012: Marked Increase In Breast Cancers Must Be Addressed, Geneva: World Health Organization.

Jemal, A., Bray, F., Mellisa, M.C., Ferlay, J. and Ward, E., 20II, Global Cancer Statistic, CA Cancer J. Clin., 6I, 43-66.

Kim, K.H., Park, H.Y., Nam, J.H., Park, J.E., Kim, J.Y., Park, M.I., et al, 2005. The Inhibitory Effect of Curcumin on the Growth of Human Colon Cancer Cells (HT-29, WiDr) in Vitro, Korea J. Gastroenterol., 45(4), 277-284.

Milosavlievic, N., Duranton, C., Djerbi, N., Puech, P., Gounon, P. and LagadicGossmann, D., 2010, Nongenomic Effects Of Cisplatin: Acute Inhibition Of Mechanosensitive Transporters and Channels Without Actin Remodeling, Mol. Cell. Pathobiol., 70(19), 75|4-7522.

Reynold, C.P. dan Maurer, B.J., 2005, Evaluating Response to Antineoplastic Drug Combinations in Tissue Culture Models, Methods Mol., I I 0, 173-183.

Sekti, D.A., Mubarok, M.F., Armandani, I., Junedy, S. and Meiyanto, E., 2010. Ekstrak Etanolik Daun Awar-awar (Ficus septica Burm. f.) Memacu Apoptosis Sel Kanker Payudara MCF-7 Melalui Penekanan Ekspresi Bcl-2, Majalah Obat Tradisional, 15, 100-104.

Siegel, R., Ma, J., Zou, Z. and Jemal, A., 2014, Cancer Statistics 2014, CA Cancer J. Clin., 64(I), 9-29.

Ueda, J.Y., Tezuka, Y., Banskota, A.H., Tran, Q.L., Hariyana, Y., Saiki, I., et al, 2002, Antiproliferative Activity of Vietnamase Medical Plants, Biol. Pharm. Bull., 25(6), 753760.

Zhao, L., Wientjes, M.G. and Au, J.L., 2004. Evaluation of Combination Chemotherapy: Integration of Nonlinear Regression, Curve Shift, isobologram, and Combination Index Analyses, Clin. Cancer Res., I0(23), 79948004. 